\title{
Varroa jacobsoni as a carrier of bacterial infections to a recipient bee host
}

\author{
Z Gliński ${ }^{\text {, J Jarosz 2* }}$ \\ ${ }^{1}$ Agricultural University, Bee Diseases Research Laboratory, Lublin; \\ ${ }_{2}^{2}$ Marie Curie-Sklodowska University, Department of Insect Pathology, \\ Akademicka 19, Lublin, Poland
}

(Received 23 December 1988; accepted 20 September 1991)

\begin{abstract}
Summary - Using Serratia marcescens as an indicator bacterium and the worker brood of the honey bee, experiments have shown that Varroa jacobsoni transmits bacterial infections to a recipient bee host. Integument and haemolymph of brood artificially contaminated with $S$ marcescens, preferably individuals with Serratia septicaemia, were the source of bacterial contamination of the mites. The infected parasites during feeding carry $S$ marcescens to about $20 \%$ of the healthy brood.
\end{abstract}

Varroa jacobsoni/ Serratia marcescens / carrier / bacterial infection / septicaemia

\section{INTRODUCTION}

One of the factors that restricts the development of insect diseases caused by bacterial invaders is low capacity of entomopathogenic bacteria to disperse throughout the host environment and ultimately to infect a susceptible host. Bacterial pathogens lack means of locomotion and active penetration via the insect integument, and therefore must rely on biotic and abiotic agents for their dispersal in an insect niche and penetration into the host haemocoel. In the case of biotic agents, bacteria may be transmitted by healthy and infected hosts, parasites and predators. The external stenophagous parasites which feed on infected hosts or on hosts killed by diseases, even though they are not susceptible to the bacteria, are capable of distributing the pathogens to their common hosts.

Bees may become susceptible to viral, bacterial and fungal infections when they are attacked by external parasites that damage their integument by ruptures or

* Correspondence and reprints 
wounds. Once infection has been initiated by $V$ jacobsoni as a vector or inducer of acute bee paralysis virus (Ball, 1983; Ball and Allan, 1986; Wiegres, 1986), regardless of the initial density of viral pathogen, a causal agent is transmitted to recipient hosts and numbers of sick bees increase in a colony. Data suggests that bacterial infections could start from microbes present on a host body surface and from microbial fiora in the bee environment that the $V$ jacobsoni mite transmits mechanically or biologically (Smirnov and Kudriavcev, 1977; Horn, 1984; Shabanov, 1984; Strick, 1986; Strick and Madel, 1986).

The transmission of bacteria by $V j a-$ cobsoni to bees has not been established, though the presence of Hafnia alvei septicaemia in colonies severely invaded by $\checkmark$ jacobsoni supports this possibility (Kutzenko, 1975). It has recently been shown that Serratia marcescens can be transmitted from artificially contaminated brood and workers of Apis mellifera to $V$ jacobsoni mites (Gliński and Jarosz, 1990). In this paper we present evidence from microbiological bioassays, using $S$ marcescens as an indicator bacterium, that show it is possible to infect healthy brood with mites fed on infected bee larvae.

\section{MATERIALS AND METHODS}

Serratia marcescens, a prodigiosin producing strain CCM 2222 obtained from the Culture Collection of Microorganisms, University of Purkinje (Brno, Czechoslovakia), was used as an indicator bacterium. This facultative bee pathogen multiplies after entering the Apis mellifera subsp mellifera haemocoel and produces a lethal septicaemia. Red colour of Serratia colonies on bacteriological media and a characteristic red colour of infected bee cadavers enables identification of $S$ marcescens on microbiological media and detection of septicaemia caused by this pathogen.
Females of $V$ jacobsoni collected from honeybee prepupae (13 days old) and pupae (15 days old) were starved for 10-12 hours before colonization of brood subcuticle injected or surface contaminated with a log phase of a broth culture of $S$ marcescens. Viable cells for inoculation of larvae were prepared by diluting an overnight culture of $S$ marcescens (incubated at $28^{\circ} \mathrm{C}$ ) to a specific concentration in insect Ringer $(130 \mathrm{mM} \mathrm{NaCl}, 5.0 \mathrm{mM} \mathrm{KCl}$ and $1.0 \mathrm{mM}$ $\mathrm{CaCl}_{2}$ ). Larvae (10 days old) were from capped cells and, after uncapping, were injected in the thoracic region with $2.0 \mu \mathrm{l}$ of bacterial suspension (about 2000 cells) or sprayed with about 50000 cells of the pathogen. Two hours later the cells were individually infested with $V$ jacobsoni, 2-3 females per larva, and artificially capped by hand with bee wax. The brood was then reared in an incubator at $34^{\circ} \mathrm{C}$. Bee larvae without any contact with $S$ marcescens but infected with the mite, and bees sprayed or injected with a sterile insect Ringer alone, served as controls.

The total number of $S$ marcescens associated with the parasite fed on brood was estimated by an agar plate colony count technique after 24 and 72 hours post-colonization. Usually 7 randomly chosen mites were individually blended in sterile insect Ringer solution (1 parasite per 0.2 $\mathrm{ml}$ ) in a glass tissue grinder. Serial 1/10 dilutions of Varroa homogenate were then prepared in the insect Ringer and $10 \mu \mathrm{l}$ of the solution was streaked in triplicate onto agar medium. The number of $S$ marcescens associated with $V$ jacobsoni was evaluated after incubation at $28^{\circ} \mathrm{C}$ for 2 days.

Multiplication of $S$ marcescens in body of bee larvae artificially injected or surface sprayed with bacterial suspension was monitored after 72 hours in larval body homogenates. Specimens were thoroughly rinsed 3 times by dipping them into $10 \mathrm{ml}$ of insect Ringer. After checking the surface sterility of larvae by rolling them on an agar plate, the larvae were blended in $10 \mathrm{ml}$ of Ringer solution. Larval homogenates were then diluted serially in a sterile insect Ringer and inoculated onto agar plates to detect the titer of $S$ marcescens present in Apis mellifera larvae.

To test for the transmission of bacteria by $V$ jacobsoni, female mites that fed 72 hours on injected or surface sprayed $A$ mellifera brood were moved onto 100 uncapped healthy prepupae (2-3 mites/specimen). The experiments 
were replicated 3 times. Brood capped with bee wax was then reared in an incubator. The symptoms of $S$ marcescens septicaemia were observed 4 and 5 days after brood exposure to infected Varroa mites. Dead larvae with developing red colour were analyzed bacteriologically to detect multiplication of $S$ marcescens.

\section{RESULTS}

$\checkmark$ jacobsoni females parasitizing honey bee larvae artificially infected with $S$ marcescens contained from many thousands to about a million bacterial cells per mite (table I). Only a few parasites carried less than one thousand cells of this pathogen. Interestingly, the number of $S$ marcescens associated with the mite increased markedly with parasitization time. Bacterial population density reached approximately $10^{6}$ cells in all mites after 72 hours of feeding of the infected brood. The indicator bacterium attained a dense population in the mite independently of the means of brood infec- tion (table I), although 24 hours postinfestation the count of bacteria present in Varroa fed on injected brood was evidently lower than that in mites fed on brood sprayed with the pathogen.

That the source of the bacterial invader for Varroa is the haemolymph of $A$ mellifera indicates the development of $S$ marcescens bacteriaemia in the host sprayed or injected with the pathogen (table II). Our bacteriological assays have shown that bee haemolymph is a suitable medium for multiplication of $S$ marcescens. Once infection had been initiated in the bee, regardless of the route of infection and initial level of the bacterial population, pathogens increased rapidly in number, usually $>5 x$ $10^{7}$ cells/larva and bees died with typical colour symptoms of $S$ marcescens septicaemia. Few control bees treated with Ringer alone, by spraying or injection, died during 3 days post-treatment, but neither symptoms of Serratia bacteriaemia nor $S$ marcescens cells were found in dead specimens.

Table I. Serratia marcescens artificially contaminating upright larvae of Apis mellifera pollutes Varroa jacobsoni mite.

\begin{tabular}{lcccc} 
Specimen & \multicolumn{5}{c}{$\begin{array}{c}\text { No of S marcescens per Varroa jacobsoni after : } \\
24 h\end{array}$} \\
& \multicolumn{5}{c}{$\begin{array}{c}72 h \\
\text { feeding on brood }\end{array}$} \\
\cline { 2 - 5 } & Sprayed & $\begin{array}{c}\text { Injected } \\
\text { with the bacterial invader }\end{array}$ & Injected \\
\hline & 7185 & 930 & 8470 & $10^{6}$ \\
$V_{1}$ & $10^{6}$ & 42 & $10^{6}$ & $10^{6}$ \\
$V_{2}$ & 3150 & 1655 & $10^{6}$ & $10^{6}$ \\
$V_{3}$ & 5825 & 110 & $10^{6}$ & $10^{6}$ \\
$V_{4}$ & 1655 & 230 & $10^{6}$ & $10^{6}$ \\
$V_{5}$ & 2715 & 1580 & $10^{6}$ & $10^{6}$ \\
$V_{6}$ & 1407 & 112 & $10^{6}$ & $10^{6}$ \\
$V_{7}$ & & & & \\
\hline
\end{tabular}


Table II. The multiplication of Serratia marcescens in upright larvae of Apis mellifera. Count $72 \mathrm{~h}$ after spray or injection of the pathogen.

\begin{tabular}{lll}
\hline Specimen & Spray & Injection \\
\hline$A_{1}$ & $N$ & $N$ \\
$A_{2}$ & $N$ & $N$ \\
$A_{3}$ & $N$ & $3 \times 10^{7}$ \\
$A_{4}$ & $N$ & $N$ \\
$A_{5}$ & $N$ & $N$ \\
$A_{6}$ & $N$ & $N$ \\
$A_{7}$ & $N$ & $N$ \\
$A_{8}$ & $N$ & $N$ \\
$A_{9}$ & $N$ & $2.5 \times 10^{7}$ \\
$A_{10}$ & $N$ & $3 \times 10^{7}$ \\
\hline
\end{tabular}

$N$ : more than $5 \times 10^{7}$ cells per larva.

It is generally claimed that predators which feed on injected hosts or on host killed by disease, even though not susceptible to the pathogens, are capable of distributing the pathogens to their common hosts. When $V$ jacobsoni females infected with $S$ marcescens were transferred to freshly uncapped healthy bee larvae, $S$ marcescens septicaemia developed in many larvae (table III).

\section{DISCUSSION}

The $V$ jacobsoni mite, because of its damage to honey bees, has received a great deal of interest worldwide (Ritter, 1981; Taber, 1986) and research has elucidated some mechanisms responsible for the deleterious effects of the parasite on the host. $V$ jacobsoni has been implicated as a vector of viral infections and inducer of latent infections caused by acute bee paralysis virus (Ball, 1983; Ball and Allen, 1986). In contrast, knowledge of the role of $V$ jacobsoni as a carrier of bacterial invader is fragmentary and still contradictory (Gliński and Jarosz, 1988). Obviously, infection per se is dependent on the pathogenic properties of microorganisms, their dosage, contact of pathogens with the host and point of entry of the pathogen into a recipient host. One of the factors that restricts the development of diseases caused by entomo-

Table III. The occurrence of Serratia marcescens septicaemia in the recipient bee larvae parasitized with $V$ jacobsoni contaminated by this bacterium.

\begin{tabular}{lll} 
Batch & \multicolumn{2}{c}{$\begin{array}{c}\text { Cumulative percentage of mortality } \\
\text { of brood with symptoms } \\
\text { of Serratia marcescens septicaemia }\end{array}$} \\
\cline { 2 - 3 } & 4 & Days post-treatment \\
\hline I: 100 worker larvae & 18.0 & 5 \\
III: 100 worker larvae & 14.0 & 21.0 \\
Mean & 12.0 & 18.0 \\
& 14.6 & 13.0 \\
\hline
\end{tabular}


athogenic bacteria is their low capacity to disperse throughout the host environment. Bacteria are generally dispersed by infected hosts, contaminated food and by mechanical or biological vectors.

As parasites, the feeding behaviour of $V$ jacobsoni may create conditions favouring transfer of bacteria within bee colonies and their penetration into the bee haemocoel by damaging host integument. Dense populations of $S$ marcescens (table I) associated with surface or interior of the mite univocally point to $V$ jacobsoni as a carrier of this facultative bee pathogen. Moreover, a luxuriant multiplication of $S$ marcescens in the host haemocoel and development of fatal septicaemia in bees fed on the parasite enables this bacteria to be transmitted to subsequent hosts (see tables II and III). Of course, leakage of haemolymph through the host wounds preferably contaminates the mouthparts of Varroa, thus creating favourable conditions for infection of healthy bee hosts by a direct introduction of bacteria into fresh wounds.

In the light of the studies on pathogenesis of Varroa disease, the impairment of host blood antibacterial factors by parasitizing mites (Gliński and Jarosz, 1984; Gliński and Jarosz, 1987) enables development of infection, multiplication of the pathogen in haemocoel and production of lethal septicaemia in the bee. In the experiments carried out, we observed a high percentage of brood dying of bacterial septicaemia after contact with mites which had been infected with $S$ marcescens during parasitization on artificially-infected bee larvae. Serratia marcescens is known to be a facultative pathogen of Apis mellifera causing the death of brood and bees. Therefore, it is reasonable to postulate that transfer of dangerous bee pathogens such as Melisococcus pluton or Ascosphaera apis by $V$ jacobsoni may constitute a threat to beekeeping. Indeed, the incidence of
European foulbrood (Trubin, 1985) and chalkbrood disease (Chmielewski and Gliński, 1987; Gliński, 1988) has been shown to increase in colonies infested with $V$ jacobsoni. We conclude that transmission of bacterial infections by $V$ jacobsoni to the honey bee constitutes another detrimental effect of this parasite on its host.

Résumé - Varroa jacobsoni en tant
que vecteur de maladies bactériennes chez son hôte, l'abeille domestique. Les mécanismes par lesquels Varroa jacobsoni, acarien ectoparasite très spécialisé, provoque des dégâts chez son hôte Apis mellifera n'ont pas été déterminés de façon définitive. Parmi les diverses possibilités de dégâts, il existe des preuves selon lesquelles $V$ jacobsoni est capable de transmettre des bactéries pathogènes à l'hôte qui l'héberge. On a utilisé comme indicateur la bactérie Serratia marcescens, qui provoque chez les larves et les nymphes d'A $m$ mellifera une septicémie, identifiable par sa coloration rouge. On a mis en évidence que ce germe pathogène reste attaché à $V$ jacobsoni, qui peut ainsi servir de vecteur. $V$ jacobsoni, qui s'alimente sur du couvain infesté artificiellement par $S$ marcescens (par vaporisation en surface ou injection sous la cuticule), contamine ses pièces buccales et la surface de son corps avec des cellules bactériennes (tableau I). Les tests microbiologiques ont également montré la multiplication de la bactérie dans l'acarien, indiquant là encore son rôle possible de vecteur. En outre, le couvain atteint de septicémie, au sein duquel $S$ marcescens se multiplie et atteint des populations élevées (tableau II), est une source de bactéries pour les acariens parasites. Le début d'une septicémie, observée sur du couvain operculé sain mais infesté par $V$ jacobsoni (tableau III), prouve de façon indubitable que l'acarien a trans- 
mis l'infection bactérienne à la colonie d'abeilles.

\section{Varroa jacobsoni / Serratia marces- cens / vecteur / bactériose / septicémie}

\section{Zusammenfassung - Varroa jacobsoni} als Überträger bakterieller Infektionen auf ihren Wirt, die Honigbienen. Die Mechanismen, durch die Varroa jacobsoni, eine außenparasitische, eng spezialisierte Milbe, ihren Wirt Apis mellifera schädigt, sind noch nicht endgültig geklärt. Neben anderen Möglichkeiten der Schädigung gibt es auch Hinweise darauf, daß Varroa bakterielle Keime auf ihren Wirt übertragen kann. Es wurde das Bakterium Serratia marcescens als Indikator benutzt, das bei Larven und Puppen von $A$ mellifera mellifera unter gleichzeitiger Rotfärbung der Tiere eine Septikämie verursacht. Es wurde festgestellt, daß dieser fakultative Krankheitskeim an Varroa jacobsoni haften bleibt und daß diese Milbe somit als Überträger von $S$ marcescens-Infektionen dienen kann. $V$ jacobsoni, die an künstlich (durch Spray oder Injektion in die Körperhöhle) mit $S$ marcescens infizierter Brut saugten, verunreinigten ihre Mundwerkzeuge und die Körperoberfläche mit Bakterienzellen (Tab I). Mikrobiologische Tests wiesen darauf hin, daß sich dieses Bakterium in der Milbe vermehrt, so daß $V$ jacobsoni auch die Rolle eines biologischen Vektors von Krankheitskeimen spielen könnte. Außerdem ist septikämische Brut, in der $S$ marcescens zu einer großen Population anwächst (Tab II), eine Bakterienquelle für parasitierende Milben. Der Ausbruch einer $S$ marcescens-Septikämie, beobachtet in gesunder verdeckelter Brut, die aber mit $V$ jacobsoni befallen war (Tab III), weist eindeutig auf die Milbe als Überträgerin bakterieller Infektionen im Bienenvolk.
Varroa jacobsoni / Serratia marcescens / Überträger / bakterielle Infektion / Septikämie

\section{REFERENCES}

Ball BV (1983) Der Zuzammenhang zwischen Varroa jacobsoni und Virus - erkrankungen der Honigbiene. Allg Dtsch Imkerztg 17, 177179

Ball BV, Allen MF (1986) The incidence of acute paralysis virus in honey bee colonies infested with the parasitic mite Varroa jacobsoni. In: Fundamental and Applied Aspects of Invertebrate Pathology (Samson RA, Vlak JM, Peters $D$, eds) 4th Int Colloq Invertebr Pathol, $p$ 151

Chmielewski M, Gliński Z (1987) Effects of Varroa jacobsoni Oud on the incidence and course of chalk-brood disease in Apis mellifera. Proc 31st Int Congr Apic August 19-25, Warsaw, Apimondia Publ House, Bucharest, p 104

Gliński Z (1988) Varroa jacobsoni affects the incidence and course of chalk-brood disease in Apis mellifera colonies. Ann Univ Mariae $\mathrm{Cu}$ rie-Sklodowska DD 43, 23-27

Gliński Z, Jarosz J (1984) Alterations in haemolymph proteins of drone honey bee larvae parasitized by Varroa jacobsoni. Apidologie 15, 329-338

Gliński Z, Jarosz J (1987) Varroa jacobsoni parasitization lowers the innate concentration of blood lysozyme of upright larvae of the worker honey bee, Apis mellifera. Proc 31st Int Congr Apic August 19-25, Warsaw, Apidmondia Publ House, Bucharest, $p 121$

Gliński Z, Jarosz J (1988) Deleterious effects of Varroa jacobsoni on the honey bee. Apiacta $23,42-55$

Gliński Z, Jarosz J (1990) Serratia marcescens artifically contaminating brood and worker honey bees pollutes Varroa jacobsoni mite. J Apic Res 29, 107-111

Horna H (1984) Zum Zusammenhang zwischen Varroa jacobsoni und Bakteriosen bei der Honigbiene. Allg Dtsch Imkerztg 18, 328-329

Kutzenko DM (1975) On the role of the gamasid mite Varroa jacobsoni (Oudemans 1904) 
transmitting hafniosis in bees. Blagovechtchensk 2, 50-52 (in Russian)

Ritter W (1981) Varroa disease of the honeybee, A mellifera. Bee World 62, 141-153

Shabanov M (1984) The role of the mites Varroa jacobsoni as a carrier of microorganisms in the bee hive. Acta Microbiol Bulgarica 15, 7882 (in Bulgarian)

Smirnov AM, Kudriavcev EA (1977) The Varroa mite and diseases from contamination. Pcelovodstvo 0(5), 13-14 (in Russian)

Strick H (1986) Die Rolle der ektoparasitischen Bienenmilbe Varroa jacobsoni Oudemans als möglicher Bakterienüberträger bei ihrem Wirt, der Honigbiene Apis mellifera Linnaeus. Diplomarbeiz an der Naturwissenchaftlichen
Fakültät der Fheinischen Friedrich-Wilhelms Universität, Bonn, $118 p p$

Strick H, Madel G (1986) Varroatose und bakterielle Sekundärseuchen. Allg Dtsch Imkerztg 20, 321-325

Taber $S$ (1986) Reports on Varroa disease of honey bees. Am Bee J 126, 430-431

Trubin AV (1985) Varroatosis and European foul brood. Pcelovodstvo 0(8), 19 (in Russian)

Wiegers FP (1986) Transmission of acute paralysis virus by the honeybee parasite Varroa jacobsoni Oud. In: Fundamental and Applied Aspects of Invertebrate Pathology (Samson RA, Vlak JM, Peters D, eds) 4th int Colloq Invertebr Pathol, Wageningen, $p 152$ 